\title{
Dynamics of the electrospondilography indices of the individuals with back pain under the influencing of the physical rehabilitation program. Physical rehabilitation of the individuals with back pain
}

\author{
O. K. Nikanorov ${ }^{\star A, D, F}$, V. V. Kormiltsev ${ }^{B, C}$, I. O. Zharova ${ }^{B, D}$, O. B. Lazareva ${ }^{E, F}$, L. D. Kravchuk ${ }^{C, E}$ \\ National University of Ukraine on Physical Education and Sport, Kyiv
}

A - research concept and design; B - collection and/or assembly of data; C - data analysis and interpretation; D - writing the article;

$\mathrm{E}$ - critical revision of the article; $\mathrm{F}$ - final approval of the article

Back pain (BP) is an important link in neurological pathology and one of the most common complaints in general medicine practice.

The purpose of the research was: scientifically and strategically substantiate and develop a comprehensive physical rehabilitation program of persons with dorsalgia in the thoracic spine and to prove its effectiveness according to the data of the electrospondilography.

Materials and methods. The study was conducted on the basis of the sports and rehabilitation club "Fifth Element" in Kyiv, 67 patients (25 men and 42 women) were taking part in our research, of the working-age with BP on the thoracic level.

Results. Based on the results of previous studies, we have developed a complex physical rehabilitation program for patients with BP on the thoracic spine, which included various tools and forms of physical rehabilitation, elements of modern fitness techniques, soft tissue and connective tissue manipulative techniques, and a cognitive method -conductive therapy.

Conclusion. The effectiveness of the developed program of patients with BP in the thoracic department was evaluated after the completion of the course - after 12 weeks. According to the data of ESG, the positive dynamics of indicators K1, K2, K3, K4 was observed in both the MG and CG. However, only in the MG of changes in K3 and K4 indicators were statistically significant.

Динаміка показників електроспондилографії осіб із болями у спині під впливом програми фрізичної реабілітації. Фізична реабілітація осіб із болями у спині

О. К. Ніканоров, В. В. Кормільцев, І. О. Жарова, О. Б. Лазарева, Л. Д. Кравчук

Біль у спині - важлива ланка в неврологічній патології та одна з найпоширеніших скарг у загальній медичній практиці.

Мета роботи - науково обґрунтувати та розробити комплексну програму фізичної реабілітації осіб із дорсалгією грудного відділу хребта, довести її ефрективність за даними електроспондилографііі.

Матеріали та методи. Дослідження здійснили на базі спортивно-реабілітаційного клубу «П'ятий елемент» у м. Києві. У дослідженні взяли участь 67 пацієнтів (25 чоловіків і 42 жінки) працездатного віку з болями у спині на торакальному рівні.

Результати. На підставі результатів попередніх досліджень розробили комплексну програму фрізичної реабілітації пацієнтів із болями у спині у грудному відділі хребта, що включала різні інструменти, фрорми фрізичної реабілітації, елементи сучасних фітнес-методик, методи маніпуляцій із м'якими тканинами і сполучною тканиною, а також когнітивний метод - терапію, яка проводиться.

Висновки. Ефеекивність розробленої програми пацієнтів із болями у спині у грудному відділі оцінювали після завершення курсу - через 12 тижнів. За даними електроспондилографії, позитивна динаміка показників К1, К2, K3, К4 визначена і за ЕГ, і за КГ. Однак тільки за ЕГ зміни показників КЗ і К4 були статистично значущими.

Ключові слова: біль у спині, фрізична медицина, реабілітаційна медицина, фізіотерапія.

Актуальні питання фрармацевтичної і медичної науки та практики. - 2019. - Т. 12, № 3(31). - С. 352-356

ARTICLE

INFO

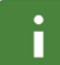

http:l/pharmed.

zsmu.edu.ualarticle

view/184249
UDC: $615.825: 616.711-002$

DOI: $10.14739 / 2409-2932.2019 .3 .184249$

Current issues in pharmacy and medicine: science and practice 2019; 12 (3), 352-356

Key words: back pain, physical medicine, rehabilitation medicine, physical therapy.

*E-mail: nikanorov@ukr.net

Received: 12.08.2019 // Revised: 20.08.2019 // Accepted: 30.08.2019 
Динамика показателей электроспондилографии лиц с болями в спине под влиянием программы физической реабилитации. Физическая реабилитация лиц с болями в спине

\section{А. К. Никаноров, В. В. Кормильцев, И. А. Жарова, Е. Б. Лазарева, Л. Д. Кравчук}

Боль в спине - важное звено в неврологической патологии и одна из самых распространенных жалоб в общей медицинской практике.

Цель работы - научно обосновать и разработать комплексную программу физической реабилитации лиц с дорсалгией грудного отдела позвоночника и доказать ее эффективность по данным электроспондилографии.

Материалы и методы. Исследование проведено на базе спортивно-реабилитационного клуба «Пятый элемент» В г. Киеве. В исследовании приняли участие 67 пациентов (25 мужчин и 42 женщины) трудоспособного возраста с болями в спине на торакальном уровне.

Результаты. На основе результатов предыдущих исследований разработали комплексную программу физической реабилитации пациентов с болями в спине в грудном отделе позвоночника, которая включала различные инструменты и формы фризиеской реабилитации, элементы современных фитнес-методик, методы манипуляций с мягкими тканями и соединительной тканью и когнитивный метод - проводящую терапию.

Выводы. Эффективность разработанной программы пациентов с болями в спине в грудном отделе оценивали после завершения курса - через 12 недель. По данным электроспондилографии, положительная динамика показателей K1, K2, K3, K4 отмечена как в ЭГ, так и в КГ. Однако только в ЭГ изменения показателей КЗ и К4 были статистически значимыми.

Ключевые слова: боль в спине, физическая медицина, реабилитационная медицина, физиотерапия.

Актуальные вопросы фрармацевтической и медицинской науки и практики. - 2019. - Т. 12, № 3(31). - С. 352-356

Chronic back pain (CBP) is one of the most acute medical and social problems that cause enormous economic damage to society (S. S. Pshyk et al., 2017) [1]. Back pain (BP) is an important link in neurological pathology and one of the most common complaints in general medicine practice (N. L. Bozhenko, 2013-2015) [2,3].

It should be emphasized that, despite the fact that in about $70 \%$ of patients, pain under the influence of treatment takes place in a relatively short period of time, there is from several weeks to a month, in patients of working age, it usually acquires a chronic relapse. The BP on the thoracic level (as the thoracalgia) occurs somewhat less frequently, compared to lesions of the lumbar and cervical levels.

The presented data convincingly testify to the necessity of an integrated approach to the restoration of patients with BP and dorsalgia, which includes not only medication preparations but also physical rehabilitation tools and methods, are adequately selected, bringing the peculiarities of the course of the pathology (S. Byuon, O. B. Lazarieva, 2012) [4,5]. In modern approaches to the treatment and physical rehabilitation of patients with BP much attention is paid to the problem of managing the CBP.

The biopsychosocial approach to constructing complex rehabilitation programs for the thematic contingent (A. B. Danilov, 2012; K. Vitoula et al., 2018) is also substantiated $[6,7]$. However, this approach has still not been reflected in domestic works.

\section{Aim}

Thus, the purpose of the research was: scientifically and strategically substantiate and develop a comprehensive physical rehabilitation program of persons with dorsalgia in the thoracic spine and to prove its effectiveness according to the data of the electrospondilography.

\section{Materials and methods}

The analysis and generalization of the data of scientific and methodological literature were carried out with the aim of the studying the relevance of the problems of BP, as well as generalization of scientific approaches to the selection of physical rehabilitation as an important component of the rehabilitation of persons with thoracalgia. Content analysis of medical records allowed to obtain information on the peculiarities of the clinical and functional condition of the patients at the stage of the primary examination and in the dynamics of rehabilitation. Electrospondilography (ESG) is a method of functional diagnosis, based on the correlation between the change in electrical conductivity of the $24^{\text {th }}$ spondylogenic skin zones and the functional condition of the spinal segments. The basis of the ESG method is the change in the electrical conductivity of the spondylogenic skin zones located in the paravertebral area symmetrically, in response to the onset of the functional blockade of the spinal segments and changes in the skin (as in the capillary) blood flow. The research was performed with the using of the diagnostic complex "Mediskrin-Vertebra" ("Medical Technologies", Ukraine), designed to measure electrochemical conductivity in twenty-four zones on the human skin, corresponding to the places of the spinal cord output. ESG data allow us to determine the physiological equilibrium in the spinal segments with 4 coefficients:

$\mathrm{K} 1$ is the main integral coefficient,

$\mathrm{K} 2$ is the coefficient of lateral asymmetry,

$\mathrm{K} 3$ is the coefficient of transverse asymmetry,

$\mathrm{K} 4$ is the coefficient of adaptive asymmetry.

The study was conducted on the basis of the sports and rehabilitation club "Fifth Element" in Kyiv, 67 patients $(25$ men and 42 women) were taking part in our research, of the working-age with BP on the thoracic level. When patients were referred to the center, they carried out an objective 
clinical examination, and patients were referred to an ESG and a doctor's consultation.

A total of 67 patients with BP in the thoracic spine were examined and created the following groups: the main group $(M G)-$ patients with BP in the thoracic spine $(n=34)$. The control group $(\mathrm{CG})$ - patients with $\mathrm{BP}$ in the thoracic spine $(\mathrm{n}=33)$.

Between the main and control groups, there were no statistically significant differences in the indicators of sex-age distribution.

Mathematical processing of numerical data of work was carried out using methods of variation statistics. Statistica 7.0 and IBM SPSS Statistics 21 applications were used for mathematical processing of numerical data.

\section{Results}

ESG diagnosis showed the results of the primary examination by the four coefficients: K1 was the total integral coefficient we had not calculated, due to the change in the norm, depending on the season, since the course of rehabilitation was 12 weeks, which corresponds to a change in the indicators norms of the total integral coefficient, then it was reliable could not have been, but we got the following results: $\overline{\mathrm{x}}=57.0$ i.u.; $\mathrm{S}=21.2$ i.u.; $\mathrm{V}=37.1 \%$; on the indicator of the coefficient of lateral asymmetry (K2) higher than the "physiological corridor" was 14 people; in the norm, the same indicator has 38 people; lower than the "physiological corridor" the same indicator has 13 people. Coefficient $\mathrm{K} 4$, as the indicator of adaptive asymmetry, higher than the "physiological corridor" have 34 people; in the norm, the same indicator has 18 people, lower than the "physiological corridor" in the same indicator has 15 people.

Coefficient $\mathrm{K} 3$, in the ascertainment experiment, 66 patients had a K3 out of normal range, and 1 (1.5\%) had a K3 score corresponding to the norm, of which the indicator was higher than the norm had 12 patients $(18 \%)$ and lower than norm had 54 patients $(80.5 \%)$.

Based on the results of previous studies, we have developed a complex physical rehabilitation program for patients with BP on the thoracic spine, which included various tools and forms of physical rehabilitation, elements of modern fitness techniques, soft tissue and connective tissue manipulative techniques, and a cognitive method -conductive therapy.

The developed program was different from the generally accepted aim of gradually restoring the maximum possible physical and social activity of patients by reducing the manifestations of CBP through methods of physical rehabilitation and the formation of self-confidence in patients and a new model of behavior by the tools of the cognitive-behavioral therapy.

In accordance with the goals set, the tools and forms of physical rehabilitation that were adapted to the individual characteristics of patients, bringing the period of rehabilitation and motor settings, were selected.

The main tasks of the adaptation period were: preparation for increasing loads; improvement of metabolic processes and trophic tissues; decompression of the vertebral column. Duration: 28-30 days. Motor settings: gentle. Applying therapeutic exercises session according to the developed methodology (duration of session - 25-35 minutes, frequency - 4-5 times per week), session in the pool of the low and medium intensity (load was 40-55\% of maximum heart rate, duration of training -35 minutes, frequency -2 times per week), soft tissue manual technique. From 3-4 weeks, individual classes of the advanced functional training started. Classes were built differentially, bringing the gender-age characteristics and level of physical condition. Method of classes performing was individual, the load was on the 15-35\% relative to the repeated maximum, the frequency was 1-2 times per week.

The main tasks of the training and correctional period were: the direction of the applied tools on the correction of the posture disorders, the formation of normal musculoskeletal stereotypes, stimulation of patients for independent exercise by physical exercises and increasing daily activity. Duration: 28-30 days. Motor settings: gentle and training. In this period, sessions of the therapeutic exercise were continued (duration of the session was 35-45 minutes, frequency was 3-4 times per week) and functional training (frequency was 2-3 times per week, load was on the $15-45 \%$ relative to repeated maximum), getting exercises to strengthen the muscle corset, as much as possible for patients. Motor density increased in classes of the aquatic exercises (load was 55-65\% of maximum heart rate, duration of training was 35 minutes, the frequency was 2 times per week). Therapeutic massage provided for the using of connective tissue techniques.

The tasks of the stabilization period of rehabilitation were: strengthening the correct posture skills, strengthening the muscle corset, ensuring stability and variability of the normal motor stereotype, increasing the physical condition of the patients. Duration: 28-30 days. Motor settings: training. Gradually, the intensity of the load in classes with functional training increased (load was $15-55 \%$ relative to repeated maximum, frequency was 2 times per week) and aquatic exercises (load was 65-80\% of maximum heart rate, duration of training was 45 minutes, frequency was 2 times for a week) increased the exposure of static load in exercises of therapeutic gymnastics (duration of classes - 50-60 minutes, frequency -3-4 times a week).

Thus, at the end of the study, the value of the K1 indicator in the MG of patients at the end of the course of rehabilitation changed from 0.98 to $1.02 \mathrm{i}$.u, while in the CG, the corresponding changes were made - from 1.02 to 1.03 i.u. The value of K2 has changed from 1.27 to $1.01 \mathrm{i} . \mathrm{u}$, in the $\mathrm{MG}$ and from 1.15 to 1.05 in the CG.

However, it should be noted that changes in the K1 and K2 indices were statistically insignificant.

The dynamics of indicators K3 and K4 in the MG were statistically significant, in contrast to changes in the CG. In $\mathrm{MG}$, an increase in the values of $\mathrm{K} 3$ from 0.91 to $0.99 \mathrm{i}$.u, and a decrease of $\mathrm{K} 4$ from 58.47 to 46.38 i.u $(\mathrm{P}<0.05)$.

An individual analysis of the relevance of the K3 indicator to the normative values among the patients in the MG and $\mathrm{CG}$ was conducted. The results of the formative experiment 
showed that the number of patients with the $\mathrm{K} 3$ index in the norm and the number of patients with the K3 index outside the norm, in the MG and CG varies statistically significant, which is confirmed by Fisher's exact criterion at the level of $\mathrm{P}<0.05$.

\section{Discussion}

The current stage of development of rehabilitation and healthcare is in the difficult social and economic conditions associated with the transition to economically new methods for managing the available resources and ensuring the possibility of more efficient use of personnel and financial capacity of treatment and prevention institutions. In connection with this, the issue of development and application of complex differential diagnostic and rehabilitation programs in the treatment of pain syndromes in the trunk is becoming urgent, allowing to short-term to hold the necessary list of manipulations, to achieve a reduction in the timing of treatment and to increase the period of remission.

CBP by frequency occupies the first place in the structure of all diseases of the musculoskeletal system is about $80 \%$ and is the most common cause of temporary disability. Significant losses of society, associated with disability, high rates of disease in young people of working age, give a special social significance to this problem.

The obtained results of the performed study confirm and supplement the data on the positive effects of physical rehabilitation on the body of patients with BP (I. O. Zharova, 2011; O. B. Lazarieva, 2013; V. V. Kormiltsev, 2014; A. M. Sainchuk, 2016), and also confirm the opinion of the group of authors that a comprehensive program of physical rehabilitation is more effective than separate elements of recovery in patients with BP (A. M. Aksonova, 2009; K. L. Boyle, 2011; N. V. Vasilieva, 2014) [8-14]. Data on the effectiveness of behavioral therapy in the complex rehabilitation of individuals with chronic non-specific back pain also confirmed (J. Chevan, P. Clapis, 2013; M. J. Stochkendahl et al., 2018) $[15,16]$.

The obtained results confirm and supplement the data on the positive impact of physical rehabilitation on the body of patients with BP and based on the above facts, we can judge the effectiveness of our proposed the physical rehabilitation program in comparison with the previously used.

\section{Conclusions}

Physical rehabilitation of persons with BP in the thoracic spine remains a little investigated problem; also need additional study of the problem of the creating the comprehensive physical rehabilitation programs in the remission stage that could be implemented in the conditions of sports and rehabilitation complexes and be aimed at prolonging the remission stage and motivating patients to adhere to a healthy lifestyle.

The physical rehabilitation program of the patients with BP in the thoracic spine was developed on the basis of the analysis of literary sources, the experience of leading specialists, results of the primary examination and taking into account pedagogical principles. The developed program differs from the generally accepted focus on the gradual maximum possible restoration of physical and social activity of patients by reducing the manifestations of chronic pain through methods of physical rehabilitation and the development of self-confidence in patients and a new model of behavior through cognitive-behavioral therapy.

The effectiveness of the developed program of patients with BP in the thoracic department was evaluated after the completion of the course - after 12 weeks. According to the data of ESG, the positive dynamics of indicators $\mathrm{K} 1$, $\mathrm{K} 2$, K3, K4 was observed in both the MG and CG. However, only in the MG of changes in K3 and K4 indicators were statistically significant.

Conflicts of interest: authors have no conflict of interest to declare. Конфлікт інтересів: відсутній.

Information about authors:

Nikanorov O. K., PhD, DSc, Associate Professor, Professor of the Department of Physical Therapy and Ergotherapy, National University of Physical Education and Sport of Ukraine, Kyiv. Kormiltsev V. V., PhD, Lecturer, Department of Physical Therapy and Ergotherapy, National University of Physical Education and Sport of Ukraine, Kyiv.

Zharova I. O., PhD, DSc, Associate Professor, Department of Physical Therapy and Ergotherapy, National University of Physical Education and Sport of Ukraine, Kyiv.

Lazareva O. B., PhD, DSc, Professor, Head of the Department of Physical

Therapy and Ergotherapy, National University of Physical Education and Sport of Ukraine, Kyiv.

ORCID ID: 0000-0002-7435-2127

Kravchuk L. D., PhD, Senior Lecturer, Department of Physical Therapy and Ergotherapy, National University of Physical Education and Sport of Ukraine, Kyiv.

\section{Відомості про авторів:}

Ніканоров О. К., д-р наук з фізичного виховання та спорту, доцент, професор каф. фрізичної терапії та ерготерапії, Національний університет фізичного виховання і спорту України, м. Київ. Кормільцев В. В., канд. наук з фрізичного виховання та спорту, викладач каф. фрізичної терапії та ерготерапії, Національний університет фізичного виховання і спорту України, м. Київ. Жарова І. О., д-р наук з фрізичного виховання та спорту, доцент каф. фрізичної терапії та ерготерапії, Національний університет фізичного виховання і спорту України, Київ.

Лазарева О. Б., д-р наук з фрізичного виховання та спорту, професор, зав. каф. фрізичної терапії та ерготерапії, Національний університет фрізичного виховання і спорту України, м. Київ.

Кравчук Л. Д., канд. наук з фізичного виховання та спорту, старший викладач каф. фізичної терапії та ерготерапії, Національний університет фрізичного виховання і спорту України, м. Київ.

Сведения об авторах:

Никаноров А. К., д-р наук по физическому воспитанию и спорту, доцент, профессор каф. физической терапии и эрготерапии, Национальный университет физического воспитания и спорта Украины, г. Киев.

Кормильцев В. В., канд.наук по физическому воспитанию и спорту, преподаватель каф. фризической терапии и эрготерапии, Национальный университет физического воспитания и спорта Украины, г. Киев.

Жарова И. А., д-р наук по физическому воспитанию и спорту, доцент каф. физической терапии и эрготерапии, Национальный университет физического воспитания и спорта Украины, г. Киев. 
Лазарева Е. Б., д-р наук по физическому воспитанию и спорту, профессор, зав. каф. фризической терапии и эрготерапии, Национальный университет физического воспитания и спорта Украины, г. Киев.

Кравчук Л. Д., канд. наук по фризическому воспитанию и спорту, старший преподаватель каф. фризической терапии и эрготерапии, Национальный университет физического воспитания и спорта Украины, г. Киев.

\section{References}

[1] Pshik, S. S., Bozhenko, N. L., Pshik, R. S., \& Bozhenko M. I. (2017). Deiaki aspekty patohenetychnoi terapii boliu spyny [Some aspects of the pathogenetic therapy of back pain]. Family medicine, 1, 127134. [in Ukrainian]

[2] Bozhenko, N. L. (2015). Bil u spyni: deiaki aspekty diahnostyky ta likuvannia [Backache: some aspects of diagnostics and treatment] Medicine of Ukraine, 4 (190). 58-65. [in Ukrainian].

[3] Bozhenko, N. L. (2013). Bolovi syndromy spyny: deiaki psykhoemotsiini aspekty i mozhlyvosti yikh korektsii [Backache syndromes: some psychoemotional aspects and possibilities for their correction]. International Neurological Journal, 8(62), 103-108. [in Ukrainian].

[4] Byuon, S., \& Son, H. (2012). The effects of proprioceptive neuromuscular facilitation and stabilizing exercise on trunk repositioning errors. Journal Of Physical Therapy Science, 24(10), 1017-1020. doi: 10.1589/jpts.24.1017

[5] Lazareva E. B. (2012). Fizicheskaja reabilitacija pri hirurgicheskom lechenii vertebrogennyh pojasnichno-krestcovyh sindromov [Physical rehabilitation after surgical treatment of lumbar spinal pain syndromes]. Kyiv. [in Russian]

[6] Danilov A. B., \& Danilov A. B. (2012). Upravlenie bolju. Biopsihosocialnyj podhod. [Pain management Biopsychosocial approach]. Moscow: AMM PRESS. [in Russian].

[7] Vitoula, K., Venneri, A., Varrassi, G., Paladini, A., Sykioti, P., Adewusi, J., \& Zis, P. (2018). Behavioral Therapy Approaches for the Management of Low Back Pain: An Up-To-Date Systematic Review. Pain And Therapy, 7(1), 1-12. doi: 10.1007/s40122-018-0099-4

[8] Zharova I., \& Shevtsova A. (2011). Obgruntuvannia vykorystannia zasobiv fizychnoi reabilitatsii v osib iz hipertonichnoiu khvoroboiu ta shyino-hrudnym osteokhondrozom [The substational using of physical rehabilitation measures of persons with arterial hypertension and cervical thoracic osteochondrosis]. Young sport science of Ukraine, 3, 126-130. [in Ukrainian].

[9] Lazarieva, O. B., \& Fedorenko, S. M. (2012). Efektyvnist vykorystannia zasobiv fitnesu $v$ prohrami fizychnoi reabilitatsii osib z vertebrohennoiu patolohiieiu [Effective use of the fitness tools in the program of physical rehabilitation of patients with vertebral pathology]. Theory and Methods of Physical Education and Sports, 4, 40-44. [in Ukrainian].

[10] Kormiltsev, V. (2014). The dynamic of heart rate variability under the physical rehabilitation process in office workers with low back pain. Theory and Methods of Physical Education and Sports, 2, 89-92.

[11] Sainchuk, A., \& Skomorokha, O. (2016). Vplyv kompleksnoi dyferentsiiovanoi prohramy fizychnoi reabilitatsii na yakist zhyttia ta bolovyi syndrom patsiientiv iz shyino-hrudnym osteokhondrozom ta hipertonichnoiu [Influence of complex differentiated program of physical rehabilitation on life quality and pain syndrome of patients with thoracocervical osteochondrosis and hypertension]. Retrieved from http://esnuir.eenu.edu.ua/bitstream/123456789/12005/1/ Anna\%20Sainchuk\%2c\%20\%d0\%9elga\%20Skomoroxa.pdf

[12] Aksenova A. M. (2009). Ispolzovanie massazha, uprazhnenij i mjagkih tehnik dlja lechenija boli v pojasnice [The use of deep reflex-muscle massage, stretching exercises and osteopathic manipulative medicine in the treatment of lumbosacralis osteochondrosis]. Physical therapy and sports medicine, 10, 19-24. [in Russian].

[13] Boyle, K. (2011). Managing a female patient with left low back pain and sacroiliac joint pain with therapeutic exercise: a case report. Physiotherapy Canada, 63(2), 154-163. doi: 10.3138/ptc.2009-37

[14] Vasileva N. V. (2014). Jeffektivnost konservativnogo kombinirovannogo lechenija nevrologicheskih projavlenij degenerativno-distroficheskih zabolevanij shejnogo otdela pozvonochnika [Effective use of the conservative combined treatment of neurological manifestations of degenerative-dystrophic diseases of the cervical spine]. Russian Neurosurgical Journal Named After Professor Polenov, 6(4), 310311. [in Russian].

[15] Chevan, J., \& Clapis, P. A. (2012). Physical therapy management of low back pain: a case-based approach. Physiotherapy Canada, 64(4), 428. doi: 10.3138/ptc.64.4.rev

[16] Stochkendahl, M., Kjaer, P., Hartvigsen, J., Kongsted, A., Aaboe, J., \& Andersen, M. et al. (2017). National Clinical Guidelines for non-surgical treatment of patients with recent onset low back pain or lumbar radiculopathy. European Spine Journal, 27(1), 60-75. doi: 10.1007/ s00586-017-5099-2 